University of Nebraska - Lincoln

DigitalCommons@University of Nebraska - Lincoln

8-30-2005

\title{
Effects of Long-Term Wastewater Application on Chemical Properties and Phosphorus Adsorption Capacity in Soils of a Wastewater Land Treatment System
}

\author{
Cong $\mathrm{Hu}$ \\ University of Nebraska - Licoln \\ Tian Zhang \\ University of Nebraska - Lincoln, tzhang1@Unl.edu \\ Yong Huang \\ University of Nebraska - Lincoln \\ Mohamed F. Dahab \\ University of Nebraska - Lincoln, mdahab1@unl.edu \\ Rao Surampalli \\ University of Nebraska-Lincoln, surampallirao@gmail.com
}

Follow this and additional works at: https://digitalcommons.unl.edu/civilengfacpub

Part of the Civil Engineering Commons

Hu, Cong; Zhang, Tian; Huang, Yong; Dahab, Mohamed F.; and Surampalli, Rao, "Effects of Long-Term Wastewater Application on Chemical Properties and Phosphorus Adsorption Capacity in Soils of a Wastewater Land Treatment System" (2005). Civil Engineering Faculty Publications. 7.

https://digitalcommons.unl.edu/civilengfacpub/7

This Article is brought to you for free and open access by the Civil Engineering at DigitalCommons@University of Nebraska - Lincoln. It has been accepted for inclusion in Civil Engineering Faculty Publications by an authorized administrator of DigitalCommons@University of Nebraska - Lincoln. 


\section{Effects of Long-Term Wastewater} Application on Chemical Properties and Phosphorus Adsorption Capacity in Soils of a Wastewater Land Treatment System

\author{
$\mathrm{CONG} \mathrm{HU},{ }^{\dagger}$ TIAN C. ZHANG, ${ }^{*, \dagger}$ \\ Y ONG H. HUANG, ${ }^{\dagger}$ \\ MOHAMED F. DAHAB,$^{\dagger}$ AND \\ RAO SURAMPALLI ${ }^{\ddagger}$ \\ 205D PKI, Civil Engineering Department, University of \\ Nebraska-Lincoln at Omaha Campus, Omaha, Nebraska \\ 68182-0178, and U.S. Environmental Protection Agency, \\ Region 7, 901 N. 5th St., Kansas City, Kansas 66101
}

The buildup of phosphorus (P) in the soil is a major factor limiting the operating life of a wastewater land treatment system. In this study, we evaluated changes of chemical properties, $\mathrm{P}$ profiles, and adsorption isotherms in the soils of a Muskegon wastewater land treatment system, which has received wastewater for $\sim 30$ years. It was found that the $\mathrm{pH}$ in the $15-\mathrm{cm}$ topsoil increased from $\sim 5-6$ in 1973 to $7.4-7.8$ in 2003; a large amount of salt (e.g., $\mathrm{Ca}, \mathrm{Mg}$ ) in wastewater was adsorbed by the soil; the soil Al content (either exchangeable or oxalate extractable) decreased, while the oxalate-extractable Fe content remained at the same level. Ca-bound $\mathrm{P}$ accounted for $\geq 70 \%$ of the total $\mathrm{P}$ adsorbed in the soil. The soil $\mathrm{P}$ adsorption capacity increased and was positively correlated with the concentration of exchangeable $\mathrm{Ca}$ in the soil. A higher concentration of exchangeable $\mathrm{Ca}$ was found in the 15$\mathrm{cm}$ topsoil, where a higher total organic carbon was present. More $\mathrm{P}$ was accumulated in the upper soil than in the deeper soil. The adsorption of $\mathrm{Ca}$ in wastewater by the soil may extend the life expectancy of the Muskegon land treatment system.

\section{Introduction}

Land disposal of municipal and industrial wastewater (with or without secondary treatment) has been applied effectively in the United States for decades. Land treatment systems can satisfactorily remove nutrients (e.g., phosphorus and nitrogen) that otherwise are difficult to degrade by biological treatment systems. On the basis of long-term observation, wastewater applications are usually limited by nitrogen or hydraulic considerations on a short-term basis, but phosphorus $(\mathrm{P})$ application may be a limiting factor over the life of a land treatment system (1). In land treatment systems, $P$ is removed from wastewater effluents primarily by sorption (including precipitation, adsorption and absorption) in the soil. The soil capacity reacting with applied $\mathrm{P}$ and the buildup of $\mathrm{P}$ in the soil are the two critical parameters for predicting the life expectancy of a land treatment system.

* Corresponding author phone: (402) 554-3784, ext 2077; fax: (402) 554-3288; e-mail: tzhang@unomaha.edu.

University of Nebraska-Lincoln at Omaha Campus.

$\ddagger$ U.S. EPA.
In the past, many researchers developed several kinetic models $(2-4)$ that are very useful for design and operation of a land treatment system. However, these models and previous studies did not focus on the prediction of the life expectancy of a land treatment system. To estimate the life expectancy of a land treatment system, the key issue is to elucidate when P movement is likely to occur and when/ how this can be predicted. In fact, this issue has puzzled both environmental and agricultural engineers for a long time. While some recent studies have focused on $\mathrm{P}$ transfer to subsurface flow $(5,6)$, no consensus has been reached on issues related to P leaching. Hesketh and Brookes (7) found that the dissolved $\mathrm{P}$ concentration in tile drainage water increased dramatically (from 0.15 to $2.75 \mathrm{mg} / \mathrm{L}$ ) when the critical soil test P (STP) value in the plow layer was above 60 $\mathrm{mg} / \mathrm{kg}$ Olsen P (termed the change point) for a silt loam. Schoumans and Groenendijk (8) reported that when the P concentration of the leachate of the topsoil $(0-20 \mathrm{~cm})$ needs to be $\leq 0.1 \mathrm{mg} \mathrm{P} / \mathrm{L}$, the $\mathrm{P}_{\mathrm{w}}$ (water-soluble $\mathrm{P}$ ) values must be reduced to $5-7 \mathrm{mg} / \mathrm{kg}$ (low soil P fertility). Sinaj et al. (9) pointed out the risks associated with assessing potential $\mathrm{P}$ losses on the basis of P mobility in the topsoil alone. McDowell et al. (10) recommended that the P sorption strength derived from the monolayer Langmuir equation be used to estimate the potential for P loss in subsurface flow when the simpler STP is unclear or unsuitable.

For both modeling and prediction of $\mathrm{P}$ leaching from soil, the maximum $\mathrm{P}$ sorption capacity of the soil $\left(P_{\max }\right)$ may be one of the most critical parameters. The $P_{\max }$ depends on the texture, oxides of $\mathrm{Al}, \mathrm{Fe}, \mathrm{Ca}$, and $\mathrm{Mg}$ compounds, and the $\mathrm{pH}$ of the soil $(3,11)$. In the literature, $P_{\max }$ is assumed to be constant for soil at a certain location and would not change with time. This assumption could be wrong for a land treatment system, where soil properties will change with the application of wastewater. Will these changes greatly affect the $P_{\max }$ ? How does the $P_{\max }$ change with time? Very limited information is available on these issues.

The objectives of this study were to evaluate (1) the effects of long-term wastewater application on major chemical properties and $\mathrm{P}$ sorption capacity of the soil of a wastewater land treatment system at Muskegon County, MI and (2) the possible relationships among several profiles, that is, different P forms, exchangeable $\mathrm{Ca}$, and 1-day $P_{\max }$ along the depth of the Muskegon soils. In addition, we further evaluated effects of changes in major soil properties on soil P leaching potential and the life expectancy of the Muskegon system.

\section{Material and Methods}

Sites Description. The Muskegon County wastewater land treatment system has been operating since 1974 (Table 1). The facility is located on 4452 ha of sandy, unproductive soil with 53 circular fields (total area $=2104$ ha farmland) on the site $(12-14)$. The system consists of collection, transmission, aeration, storage, irrigation, soil, crop, and drainage components. The facility currently treats $98410 \mathrm{~m}^{3} / \mathrm{d}$ (26 MGD) of wastewater. About $50 \%$ of the wastewater comes from a paper mill, $\sim 25 \%$ from other industries, and $\sim 25 \%$ from domestic wastewater. Before it is sprayed on the soil, wastewater is pretreated in full-mixing basins and aeratingsettling basins, and then stored in two storage lagoons (345 ha each). The pretreatment processes remove $>90 \%$ of the original organic compounds and $\sim 30 \%$ of $\mathrm{P}$ in the wastewater (Tables 1 and 3) (14).

The major soil types of the site are categorized as Rubicon, Roscommon, AuGres, and Granby sands (Tables 1 and 2). Originally, these soils were very friable and strongly acidic 


\section{TABLE 1. Some Design and Operational Parameters of the Muskegon System $(1,13,14)$}

av wastewater (WW) flow

WW applied in 1974-2001 (cm)

$\mathrm{P}$ loading $\left(\mathrm{kg} / \mathrm{m}^{2}\right)$

crop type

irrigation systems

WW application rate

annual precipitation/evaporation
$Q=98410 \mathrm{~m}^{3} / \mathrm{d}$ (26 MGD) in 2004 (design capacity = $158970 \mathrm{~m}^{3} / \mathrm{d}, 42$ MGD)

Rubicon soil = 12 055; Roscommon = 8666; AuGres = 9601

Rubicon soil $=0.12 ;$ Roscommon $=0.03$; AuGres $=0.09$

corn, soybean, and alfalfa, rotated yearly in each irrigation field

sprinkler (center pivot), time on/off varies; usually, the sprinkler will rotate one circle per day

Rubicon soil (best) and Roscommon (2nd best) $=2.5 \mathrm{~cm} / \mathrm{d}$ for $\sim 180 \mathrm{~d}$;

AuGres $=0.8-1.5 \mathrm{~cm} / \mathrm{d}$ for $180 \mathrm{~d}$; whole site av weekly rate $=7.6 \mathrm{~cm}$ for $\sim 180 \mathrm{~d}$ av rainfall in $1974-2001=85.1 \mathrm{~cm}$; annual evaporation $=76.2 \mathrm{~cm}$

TABLE 2. Topsoil Physical Properties in 1973 (13)

soil type

Rubicon

AuGres

Roscommon

Granby composition

medium, fine sand ${ }^{a}$

medium, fine sand

medium, fine sand

medium, fine sand $+1 \%$ clay hydraulic
conductivity $(\mathrm{cm} / \mathrm{h})$

32

34

16

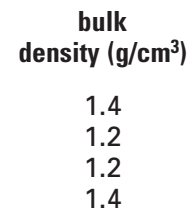

1.4

\author{
volumetric \\ water content $(\%)$
}

19

25

30

25

a Sand diameter ranging from 100 to $500 \mu \mathrm{m}$.

TABLE 3. Wastewater Characteristics in Influent and Effluent of the Muskegon System ${ }^{a}$

\begin{tabular}{llll}
\multicolumn{1}{c}{ parameter } & \multicolumn{1}{c}{$\begin{array}{c}\text { plant } \\
\text { influent }\end{array}$} & \multicolumn{1}{c}{$\begin{array}{c}\text { influent of } \\
\text { each field }\end{array}$} & \multicolumn{1}{c}{$\begin{array}{c}\text { plant } \\
\text { effluent }\end{array}$} \\
$\mathrm{BOD}(\mathrm{mg} / \mathrm{L})$ & $257 \pm 3.5$ & $5.15 \pm 4.5$ & $<2$ \\
$\mathrm{pH}$ & $7.08 \pm 0.24$ & $8.5 \pm 0.34$ & $7.5 \pm 0.31$ \\
total $\mathrm{P}(\mathrm{mg} / \mathrm{L})$ & $3.06 \pm 0.22$ & $1.88 \pm 0.18$ & $0.03 \pm 0.01$ \\
$\mathrm{SO}_{4}{ }^{2-}(\mathrm{mg} / \mathrm{L})$ & $267 \pm 7.68$ & $337 \pm 11.68$ & $184 \pm 8.35$ \\
$\mathrm{NH}_{3}(\mathrm{mg} / \mathrm{L})$ & $7.24 \pm 0.85$ & $1.32 \pm 0.17$ & $0.09 \pm 0.03$ \\
$\mathrm{Ca}^{2+}(\mathrm{mg} / \mathrm{L})$ & $\mathrm{NM}$ & $123 \pm 8.2$ & $119 \pm 11.5$ \\
$\mathrm{Mg}^{2+}(\mathrm{mg} / \mathrm{L})$ & $\mathrm{NM}$ & $20 \pm 2.8$ & $28 \pm 3.3$ \\
$\mathrm{Fe}^{2+/ 3+}(\mathrm{mg} / \mathrm{L})$ & $\mathrm{NM}$ & $<0.5$ & $<0.5$ \\
$\mathrm{Al}^{3+}(\mathrm{mg} / \mathrm{L})$ & $\mathrm{NM}$ & $<0.01$ & $<0.01$
\end{tabular}

a Plant influent: wastewater before any pretreatment. Influent of each field: the Muskegon plant uses the sample taken from the transient ditch between the lagoon outlet and the pump station as the influent of each field. Plant effluent is sampled from the final outfall of the plant. The BOD, $\mathrm{pH}$, total $\mathrm{P}, \mathrm{SO}_{4}{ }^{2-}$, and $\mathrm{NH}_{3}$ values are the monthly averages \pm standard deviations that were obtained from a routine Muskegon report to the state of Michigan (September 2003). $\mathrm{Ca}^{2+}, \mathrm{Mg}^{2+}, \mathrm{Fe}^{2+/ 3+}$, and $\mathrm{Al}^{3+}$ are measured results of a composite sample of three grab samples taken in this study. NM = not measured.

(pH 3-5), except the Granby, which is neutral at the top and slightly acidic at the subsoil (13). The soil distribution of the sites is very uniform (12). The mechanical composition, soil water characteristics, bulk density, and hydraulic conductivity are remarkably similar among different samples taken from different fields of the same type of soil $(12,13)$. We tested variations of the concentrations of exchangeable $\mathrm{Na}, \mathrm{K}, \mathrm{Mg}$, and $\mathrm{Ca}$, Bray-1 P, and total organic carbon (TOC) in the top $60 \mathrm{~cm}$ soils sampled from fields $5,6,8,9,17,18,28,29$, and 34 . We found that each type of soil also has very similar chemical properties, even though they may be sampled from different fields, which allows use of only a few samples to obtain the information with negligible error.

Soil Sampling and Preparation. Soil samples were taken from fields 6 (Rubicon), 29 (Roscommon), and 17 (AuGres) using a $5 \times 15 \mathrm{~cm}(2 \times 6$ in.) soil sampling kit (AMS Inc, ID). No soil samples were taken from fields of the Granby soil, because little wastewater was applied on them due to their low hydraulic conductivity. At each field, we selected three locations along the line toward the center of the field that were $20 \mathrm{~m}$ away from each other; we then took soil core samples along the depth of the soil. Soil samples were divided into $15-\mathrm{cm}$ depth increments from the surface $(0 \mathrm{~cm})$ to the groundwater table (about $244-274 \mathrm{~cm}$ ). In addition, the
Muskegon plant provided some of the original soil sampled in 1973, 1976, and 1977. These soil samples were taken using a hydraulic-powered soil-sampling machine; once in the laboratory, they were separated according to their depth and then dried, sieved, and stored in glass bottles in a dark room at the Muskegon plant.

Once in the laboratory, each of these soil samples was dried at room temperature, passed through a 2-mm sieve, and stored in a glass jar (bottle) with a cap. In this study, one composite soil sample was made for each increment by mixing the same quantity of the three sieved soil samples that were taken at the same depth.

P Adsorption Isotherms. P sorption isotherms were obtained by continuously agitating batch reactors for $24 \mathrm{~h}$ (15). Each batch reactor was a 50-mL equilibration tube containing $25 \mathrm{~mL}$ of $0.01 \mathrm{M} \mathrm{CaCl}_{2}$ solution, $2 \mathrm{~g}$ of air-dried soil, and a specified P concentration of $0.5,1,2,5,7$, or 10 $\mathrm{mg} / \mathrm{L}$, respectively. For a long-term sorption test, two sets of the initial $\mathrm{P}$ concentration in the batch reactors (tubes) were $0.5,1,2,5,7,10 \mathrm{mg} / \mathrm{L}$ and 5, 7, 10, 20, 30, $40 \mathrm{mg} / \mathrm{L}$. For each $P$ concentration, multiple batch reactors were prepared; at each predetermined time interval, one reactor was removed from the rotating box (with a $30 \mathrm{rpm}$ rotating speed) and sacrificed for sample analysis. The predetermined time intervals were $2,3,24,48$, and $100 \mathrm{~h}$ for the first set of the test and 300, 1000, and $2000 \mathrm{~h}$ for the second set.

Chemicals and Analytical Methods. Unless otherwise indicated, all aqueous solutions were prepared with deionized water (DI) with resistivity between 15 and $18 \mathrm{M} \Omega \mathrm{cm}$ (Barnstead Nanopure series 550, Barnstead/Thermolyne Co., Dubuque, IA). All commercially available chemicals were from VWR Scientific and were ACS (American Chemistry Society) or high-performance liquid chromatography (HPLC) grade and used as received. All tests and analyses were conducted at room temperature $\left(24 \pm 1^{\circ} \mathrm{C}\right)$. In this study, the average of the triplicates $(n=3)$ of a composite soil (sampled at three locations) at each depth is reported.

We define $1 \mathrm{M} \mathrm{NH}_{4} \mathrm{Cl}$-extractable $\mathrm{P}$ as easily removable or labile $\mathrm{P}(16), \mathrm{NaOH}$-extractable $\mathrm{P}$ as Fe-/Al-associated $\mathrm{P}$, and $\mathrm{HCl}$-extractable $\mathrm{P}$ as Ca-/Mg-associated P (17). A 2-g air-dried soil sample was sequentially extracted with $20 \mathrm{~mL}$ of $1 \mathrm{M} \mathrm{NH}_{4} \mathrm{Cl}$ (adjusted to $\mathrm{pH} 7.0$ ) with $2 \mathrm{~h}$ of shaking, 0.1 $\mathrm{M} \mathrm{NaOH}$ with $17 \mathrm{~h}$ of shaking, and $0.5 \mathrm{M} \mathrm{HCl}$ with $24 \mathrm{~h}$ of shaking. After each extraction, the contents were centrifuged for $15 \mathrm{~min}$ at $3620 \mathrm{~g}$ and filtered through a $0.45-\mu \mathrm{m}$ filter (Pall Gelman Lab., Ann Arbor, MI). The inorganic P in the aforementioned soil extracts was determined colorimetrically 
TABLE 4. Changes in Chemical Properties of 15-cm Topsoils ${ }^{a}$

\begin{tabular}{|c|c|c|c|c|c|c|c|c|c|}
\hline \multirow[b]{2}{*}{ soil type } & \multicolumn{9}{|c|}{ properties for 1973 vs 2003 ( \pm standard deviation) } \\
\hline & $\mathrm{pH}$ & $\mathrm{Fe}^{b}$ & $\mathbf{A l} \mathbf{l}^{\mathrm{c}}$ & ex-Cad & total Ca & ex-Mge & TOC $^{f}$ & Bray-1 P & $P_{\max ^{g}}$ \\
\hline Rub & $\begin{array}{l}5.0 \\
7.8 \pm 0.34\end{array}$ & $\begin{array}{l}850 \\
784 \pm 20\end{array}$ & $\begin{array}{l}360 \\
<D L\end{array}$ & $\begin{array}{l}82 \\
1205 \pm 45\end{array}$ & $\begin{array}{l}1800 \\
2800 \pm\end{array}$ & $\begin{array}{l}8 \\
72.5 \pm 15\end{array}$ & $\begin{array}{l}3 \\
4 \pm 0.11\end{array}$ & s & $420 \pm 24$ \\
\hline AuGre & $\begin{array}{l}5.5 \\
7.4 \pm 0.26\end{array}$ & $\begin{array}{l}1189 \\
1300 \pm 47 \\
720\end{array}$ & $\begin{array}{l}872 \\
<\mathrm{DL} \\
560\end{array}$ & $\begin{array}{l}310 \\
1159 \pm 36 \\
420\end{array}$ & $\begin{array}{l}1800 \\
2700 \pm 90 \\
2700\end{array}$ & $\begin{array}{l}49 \\
76.5 \pm 11 \\
78\end{array}$ & $\begin{array}{l}1.14 \\
1.84 \pm 0.15 \\
1.48\end{array}$ & $\begin{array}{l}11.5 \\
17.5 \pm 1.1 \\
9.6\end{array}$ & $\begin{array}{l}115 \\
454 \pm 20 \\
137\end{array}$ \\
\hline Rosco & $\begin{array}{l}5.6 \\
7.8 \pm 0.22\end{array}$ & $673 \pm 23$ & $\begin{array}{l}560 \\
<\mathrm{DL}\end{array}$ & $\begin{array}{l}420 \\
1359 \pm 47\end{array}$ & $4180 \pm 110$ & $98.5 \pm 17$ & $\begin{array}{l}1.48 \\
2.68 \pm 0.14\end{array}$ & $13.8 \pm 1.1$ & $312 \pm 17$ \\
\hline
\end{tabular}

a All units are $\mathrm{mg} / \mathrm{kg}$ of soil, except $\mathrm{pH}$ (unitless). Data on top are for 1973 and those on the bottom are for 2003 ( \pm standard deviation). $\mathrm{pH}$, $\mathrm{Ca}, \mathrm{Mg}, \mathrm{P}$, and $P_{\max }$ values for 1973 are from an U.S. EPA report (13). Other data (Fe, Al, TOC) for 1973 were measured in this study with the original soil sampled during 1973 (provided by the Muskegon plant). All data for 2003 were obtained from this study. ${ }^{b}$ Oxalate-extracted Fe. ${ }^{c}$ Oxalateextracted $\mathrm{Al} ;<\mathrm{DL}=$ lower than the detection limit. ${ }^{d}$ Exchangeable $\mathrm{Ca} .{ }^{e}$ Exchangeable $\mathrm{Mg} .{ }^{f}$ Total organic carbon. ${ }^{g}$ One-day maximum $\mathrm{P}$ sorption capacity.

using the ascorbic acid reduction method (18). Total P was determined by the perchloric acid digestion method (19).

Soil $\mathrm{pH}$ was determined by measuring the $\mathrm{pH}$ of a 1:2 soil and water suspension with an ORION semimicro $\mathrm{pH}$ probe (20). Oxalate-extractable $\mathrm{Al}(\mathrm{Ox}-\mathrm{Al}), \mathrm{Fe}(\mathrm{Ox}-\mathrm{Fe})$, and $\mathrm{P}(\mathrm{Ox}-\mathrm{P})$ were determined by extracting soil with $0.2 \mathrm{M}$ oxalic acid + $0.2 \mathrm{M}$ ammonium oxalate ( $\mathrm{pH}$ 3.0) (21); the suspension was equilibrated for $4 \mathrm{~h}$ in the dark with continuous shaking, centrifuged, filtered through a $0.45-\mu \mathrm{m}$ filter, and analyzed for $\mathrm{Al}, \mathrm{Fe}$, and $\mathrm{P}$. Exchangeable-Al was extracted with $1 \mathrm{~N} \mathrm{KCl}$ with $2 \mathrm{~h}$ of shaking (22). Al (Ox- and exchangeable-Al) was determined using a spectrophotometer (Hach DR/2000). Fe was analyzed with an atomic adsorption spectrometer (Model 3110 , Perkin-Elmer) at a wavelength of $248.3 \mathrm{~nm}$. P was measured with a spectrophotometer (Spectronic 21, Milton Roy) at a wavelength of $882 \mathrm{~nm}$.

Exchangeable $\mathrm{Ca}$ and $\mathrm{Mg}$ were measured by an HPLC system (Dionex DX-500, Dionex Co., Sunnyvale, CA). To prepare samples, $5 \mathrm{~g}$ of soil was mixed with $1 \mathrm{M}$ ammonium acetate ( $\mathrm{pH} 7$ ). The mixture was shaken end-over-end for 5 min (23) and then filtered with a $0.45-\mu \mathrm{m}$ filter. The filtrate was then used for HPLC analysis. To measure $\mathrm{Ca}^{2+}$ and $\mathrm{Mg}^{2+}$, a conductivity detector (CD 20) and a self-regenerating suppressor (SRS, CSRS-II 4-mm) with a 100-mA current were used. An IonPac CG12A $4 \times 50 \mathrm{~mm}$ precolumn and a $4 \times 250$ mm separation column were used with $22 \mathrm{mM} \mathrm{H}_{2} \mathrm{SO}_{4}$ eluent at a flow rate of $1.2 \mathrm{~mL} / \mathrm{min}$. Total organic matter was estimated by the loss-on-ignition method (24). The $\mathrm{CaCO}_{3}$ content of the soil samples was determined as per the standard procedure (25).

\section{Results and Discussion}

Changes in Soil Chemical Properties. As shown in Tables 3 and 4, the chemical properties of the Muskegon soils have changed, probably due to the long-term application of the wastewater with a high $\mathrm{pH}(\sim 8.5)$ and a high salt content (Ca, Mg, etc.). The soil pH increased from 4 to 6 in 1973 to $>7$ in 2003 (Table 4), indicating that the soil might have adsorbed some $\mathrm{OH}^{-}$ions or that $\mathrm{H}^{+}$ions in the soils might have been replaced by other cations, such as $\mathrm{Na}, \mathrm{K}, \mathrm{Ca}, \mathrm{Mg}$, in the wastewater.

The concentration of oxalate-extracted Fe in both 1973 and 2003 is the same order of magnitude (Table 4). Since the concentration of Fe in both influent and effluent is $<0.5$ $\mathrm{mg} / \mathrm{L}$ (Table 3), it is possible that the Fe precipitates still remain in the soil. Unlike Fe ions, the concentration of oxalate-extracted $\mathrm{Al}$ in 2003 is lower than the detection limit (Table 4). Additional measurements at different depths of the soils indicate that there is no measurable exchangeable $\mathrm{Al}$ in the deeper soils in 2003. Therefore, the extractable Al was lost through the drainage water. The difference between the $\mathrm{Fe}$ and $\mathrm{Al}$ accumulation at the Muskegon site may be due to the different effects of the soil $\mathrm{pH}$ on their activity, which is maintained by their oxides and hydroxides, and will decrease $\sim 1000$-fold for each unit increase in $\mathrm{pH}(26)$. When the $\mathrm{pH}$ is above 7 , the activity of $\mathrm{Al}^{3+}$ is below $10^{-10} \mathrm{M}$ and $\mathrm{Fe}^{3+}$ is below $10^{-16} \mathrm{M}(26)$. Most of the Fe ions form some insoluble minerals, while the $\mathrm{Al}$ ions, besides forming some insoluble minerals, become soluble as $\mathrm{Al}(\mathrm{OH})_{4}{ }^{-}$and $\mathrm{Al}(\mathrm{OH})_{5}{ }^{2-}$ (26), which will leach out in the drainage water.

In this study, the exchangeable $\mathrm{Ca}$ and $\mathrm{Mg}$ were selected as the parameters to represent the $\mathrm{Ca}$ and $\mathrm{Mg}$ adsorbed in the soil. This kind of $\mathrm{Ca}$ and $\mathrm{Mg}$ is water soluble and rapidly exchangeable, so they are ready to react with phosphate (27, 28). As shown in Table 4 , the exchangeable Ca concentrations in 2003 are almost 10 times higher than those in 1973; the exchangeable $\mathrm{Mg}$ in the soils also increased, especially in Rubicon soil. The total Ca concentration did not increase as much as exchangeable Ca. It seems that the soils have reached their maximum $\mathrm{Ca}$ or $\mathrm{Mg}$ adsorption capacity because the $\mathrm{Ca}$ or Mg concentrations in influent and effluent are almost the same (Table 3 ). In addition, we found that the exchangeable $\mathrm{Ca}$ adsorbed in the $15-\mathrm{cm}$ topsoil of Rubicon (field 6) was $82,895,1070$, and $1205 \mathrm{mg} / \mathrm{kg}$ of soil for soils sampled in 1973, 1976, 1977, and 2003, respectively. Therefore, the soil at the site can achieve its equilibrium for Ca adsorption after just a few years of wastewater application.

Although the Ca adsorption capacity of sandy soil is quite low, the Muskegon soil can accumulate $>1300 \mathrm{mg} / \mathrm{kg}$ exchangeable $\mathrm{Ca}$ in the $15-\mathrm{cm}$ topsoil. This may be because the increase in the soils' $\mathrm{pH}$ and TOC results in a great increase in the soils' Ca adsorption capacity by promoting some chemical reactions of Ca within the soils (29). In addition, $\sim 45 \%$ [ $=(337-184) / 337$, Table 3 ] of the sulfate in wastewater was removed by the system, which could increase the soil surface charge and thereby facilitate the $\mathrm{Ca}$ adsorption $(1,27-30)$.

Due to the complexity of the soil environment, however, the above analyses may not be correct. For example, the adsorbed sulfate may be reduced to sulfide by sulfatereducing bacteria, which would change the cation exchange capacity of the soil. Also, it is not known how the soil $\mathrm{P}$ adsorption capacity or the cation exchange capacity changes as a function of the soil TOC. Further studies are needed to evaluate why $\mathrm{Ca}$ accumulates at the Muskegon site and whether this $\mathrm{Ca}$ accumulation phenomenon exists in other less sandy soils as well.

Profiles of Different Forms of P, Exchangeable Ca, and $\boldsymbol{P}_{\max }$. The concentration of labile $\mathrm{P}$ is very low in the Muskegon soils (Table 5). There is no measurable labile $P$ at the depth of $137-213 \mathrm{~cm}$ in AuGres soil. The statistical analyses indicate that the labile $P$ distribution is not correlated with that of the total $\mathrm{P}$ or Fe-bound $\mathrm{P}$, or Ca-bound and/or Mg-bound $\mathrm{P}$ (Ca/Mg-bound P) at the Muskegon site (data not shown). This is particularly true for Roscommon soil (field 29), where the labile $\mathrm{P}$ in the deeper soil is higher than that in the topsoil, 


\begin{tabular}{|c|c|c|c|c|}
\hline \multicolumn{5}{|c|}{ TABLE 5. Profiles of Different Forms of $P(\mathrm{mg} / \mathrm{kg} \pm \mathrm{SD})$ in } \\
\hline depth, cm & labile $\mathbf{P}$ & $\begin{array}{c}\text { Fe-bound } \\
P\end{array}$ & $\begin{array}{l}\text { Ca-/Mg- } \\
\text { bound } \mathrm{P}\end{array}$ & total P \\
\hline \multicolumn{5}{|c|}{ Rubicon } \\
\hline $0-15$ & $6.23 \pm 0.36$ & $9.82 \pm 1.52$ & $276.71 \pm 1.81$ & $305.91 \pm 5.78$ \\
\hline $15-31$ & $2.68 \pm 0.19$ & $15.42 \pm 2.91$ & $287.24 \pm 3.90$ & $321.09 \pm 4.10$ \\
\hline $31-46$ & $2.13 \pm 0.12$ & $12.22 \pm 1.58$ & $213.53 \pm 2.07$ & $241.50 \pm 4.94$ \\
\hline $46-61$ & $1.71 \pm 0.07$ & $17.56 \pm 1.85$ & $199.77 \pm 4.56$ & $231.15 \pm 1.20$ \\
\hline $61-91$ & $1.43 \pm 0.01$ & $11.76 \pm 2.19$ & $128.20 \pm 2.54$ & $154.73 \pm 3.20$ \\
\hline $107-122$ & $0.9 \pm 0.01$ & $6.97 \pm 1.22$ & $58.75 \pm 3.17$ & $75.06 \pm 4.15$ \\
\hline $137-152$ & $0.96 \pm 0.01$ & $7.12 \pm 1.36$ & $53.94 \pm 1.49$ & $64.43 \pm 2.21$ \\
\hline $168-183$ & $0.78 \pm 0.05$ & $6.23 \pm 1.12$ & $61.66 \pm 4.72$ & $71.27 \pm 3.86$ \\
\hline $198-213$ & $0.75 \pm 0.07$ & $6.54 \pm 1.25$ & $59.88 \pm 1.17$ & $66.60 \pm 3.38$ \\
\hline \multicolumn{5}{|c|}{ AuGres } \\
\hline $0-15$ & $3.12 \pm 0.12$ & $23.92 \pm 2.77$ & $257.87 \pm 0.38$ & $301.29 \pm 1.83$ \\
\hline $15-31$ & $1.2 \pm 0.11$ & $28.06 \pm 2.87$ & $167.41=$ & $201.51 \pm 2.13$ \\
\hline $31-46$ & $1.05 \pm 0.04$ & $44.62 \pm 4.68$ & $73.39 \pm 1.13$ & $130.80 \pm 0.27$ \\
\hline $46-61$ & $0.93 \pm 0.01$ & $28.06 \pm 5.69$ & $62.01 \pm 1.41$ & $101.73 \pm 2.44$ \\
\hline $61-91$ & $0.67 \pm 0.01$ & $14.94 \pm 0.74$ & $78.65 \pm 1.66$ & $92.70 \pm 2.41$ \\
\hline $107-122$ & $0.66 \pm 0.01$ & $19.89 \pm 0.07$ & $52.04 \pm 0.67$ & $70.04 \pm 0.06$ \\
\hline $137-152$ & $<\mathrm{DL}^{b}$ & $5.66 \pm 0.90$ & $28.32 \pm 1.18$ & $35.84 \pm 0.21$ \\
\hline $168-183$ & $<\mathrm{DL}$ & $4.10 \pm 0.56$ & $24.46 \pm 0.38$ & $28.70 \pm 1.07$ \\
\hline $198-213$ & $<\mathrm{DL}$ & $3.68 \pm 0.44$ & $14.08 \pm 1.35$ & $18.4 \pm 0.79$ \\
\hline \multicolumn{5}{|c|}{ Roscommon } \\
\hline-15 & $0.67 \pm 0.03$ & $13.14 \pm 1.20$ & 96.12 & $117.14 \pm 0.42$ \\
\hline $15-31$ & $0.59 \pm 0.02$ & $11.98 \pm 1.43$ & $56.59 \pm 4.81$ & $77.98 \pm 2.25$ \\
\hline $31-46$ & $0.73 \pm 0.02$ & $1.69 \pm 0.43$ & $21.80 \pm 1.68$ & $30.69 \pm 0.64$ \\
\hline $46-61$ & $0.66 \pm 0.02$ & $5.59 \pm 1.27$ & $38.53 \pm 2.07$ & $51.59 \pm 1.04$ \\
\hline $61-91$ & $1.32 \pm 0.02$ & $1.84 \pm 0.64$ & $33.25 \pm 2.46$ & $42.84 \pm 0.23$ \\
\hline $107-122$ & $1.04 \pm 0.08$ & $3.27 \pm 1.03$ & $27.86 \pm 3.01$ & $39.27 \pm 0.38$ \\
\hline $137-152$ & $1.12 \pm 0.11$ & $4.51 \pm 0.68$ & $28.14 \pm 2.62$ & $40.51 \pm 0.15$ \\
\hline $168-183$ & $1.14 \pm 0.22$ & $3.52 \pm 0.67$ & $27.94 \pm 2.90$ & $39.52 \pm 2.10$ \\
\hline $198-213$ & $1.73 \pm 0.32$ & $4.59 \pm 0.57$ & $32.67 \pm 3.28$ & $45.59 \pm 3.55$ \\
\hline
\end{tabular}

a All data are the average of triplicates of the composite sample at each depth. The Al content is so low that no procedure was done to separate the Al-bound P from others. ${ }^{b}<\mathrm{DL}=$ lower than the detection limit.

even though more $\mathrm{P}$ accumulated in the topsoil (Table 5).

The concentration of Fe-bound $\mathrm{P}$ in AuGres is the highest among the three soils. The Roscommon has a similar level of Fe-bound P with Rubicon, even in the topsoil. The Febound $\mathrm{P}$ may not be related to the different loading rates of $\mathrm{P}$ application because the P mass loading in AuGres is 0.090 $\mathrm{kg} / \mathrm{m}^{2}$ from 1973 to 2001 (Table 1), which is lower than that in Rubicon $\left(0.12 \mathrm{~kg} / \mathrm{m}^{2}\right)$ but higher than that in Roscommon $\left(0.03 \mathrm{~kg} / \mathrm{m}^{2}\right)$. It has been reported that Fe oxides are the most active sorbents in the calcareous soils $(30,31)$. We found that the $\mathrm{CaCO}_{3}$ content in the top 60 -cm soil are all below $2 \%$, indicating that the original sandy, acidic soils have not changed to calcareous soils, even though they received a large amount of Ca. Therefore, we believe that, after the soil $\mathrm{pH}$ rose to 7, considering the low activity of $\mathrm{Fe}^{3+}$, the applied $\mathrm{P}$ should mainly react with $\mathrm{Ca}$ and $\mathrm{Mg}$ ions in Muskegon soils.

As shown in Figure 1, the exchangeable $\mathrm{Ca}$, Ca-bound $\mathrm{P}$, and $P_{\max }$ for the three soils decrease with depth. Most of Ca is accumulated in the $15-\mathrm{cm}$ topsoil, where a higher TOC was present (Figure 1). For the soil, where the organic matter forms the major variable-charge component, $\mathrm{Ca}^{2+}$ is probably adsorbed by complex formation through electrostatic attraction of $\mathrm{Ca}^{2+}$ onto the carboxyl and phenolic hydroxyl groups $(29,32)$. In all three soils, the concentration of exchangeable Ca reduces very quickly in the first $60 \mathrm{~cm}$ near the top and reduces gradually after that, except for AuGres soil.

In general, Rubicon has the highest concentration of Caand Mg-bound P at different depths, followed by AuGres and Roscommon. The Ca- and Mg-bound P are the major forms of $\mathrm{P}$ adsorbed in the soils, accounting for $>70 \%$ of the total $\mathrm{P}$ adsorbed in the soils (Table 5). On the basis of the P
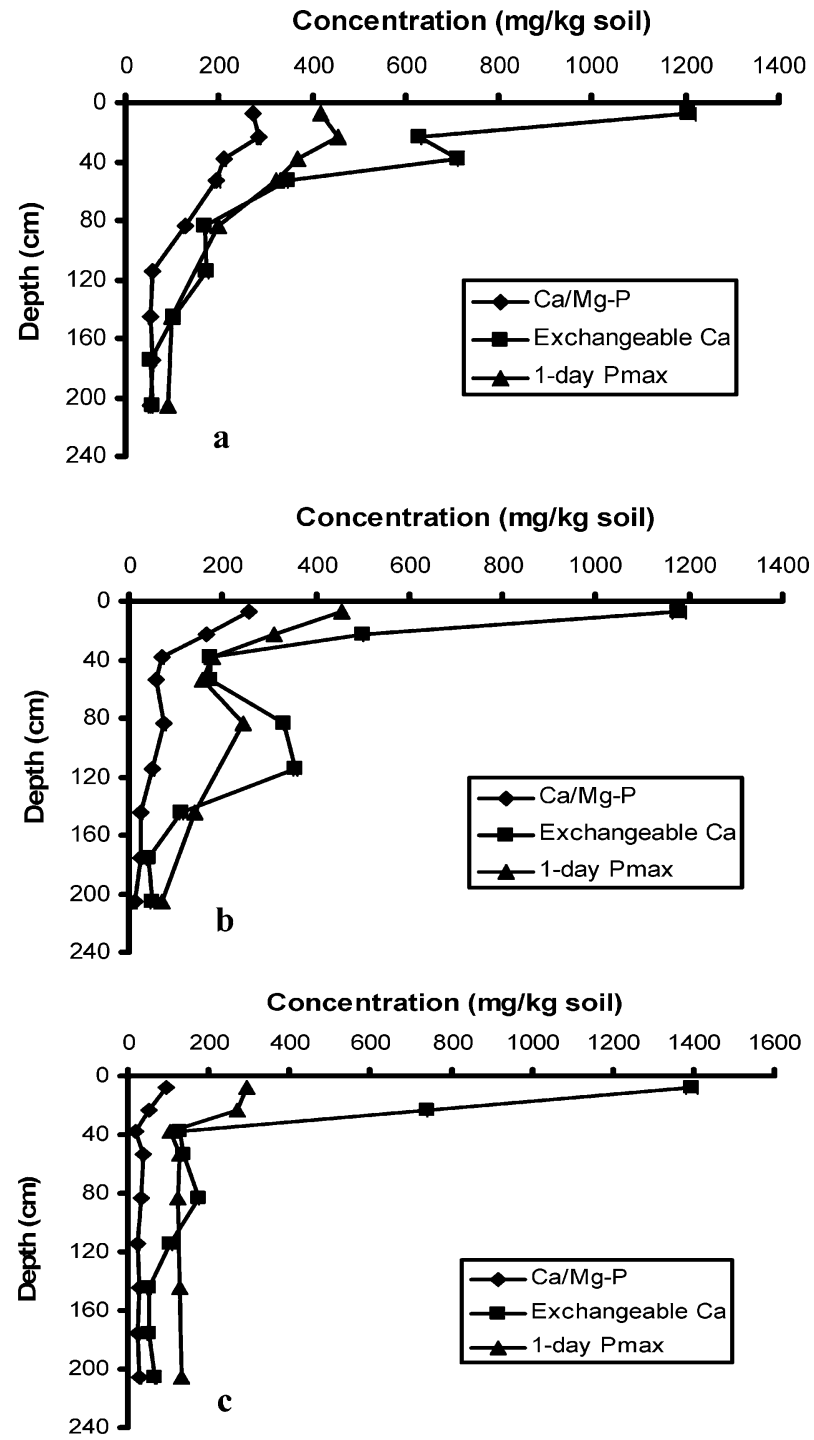

FIGURE 1. Profiles of exchangeable $\mathrm{Ca}, \mathrm{Ca}-/ \mathrm{Mg}$-bound $\mathrm{P}$, and 1-d $\boldsymbol{P}_{\max }$ in (a) Rubicon, (b) AuGres, and (c) Roscommon soils sampled at 2003. Values and error bars (buried in the marks) represent the average \pm 1 standard deviation, respectively, from triplicates of a composite sample at each depth for $\mathrm{Ca}-/ \mathrm{Mg}$-bound $\mathrm{P}$ and Exchangeable $\mathrm{Ca}$.

loading (Table 1), the difference in the total $\mathrm{P}$ concentration adsorbed in the different soils may be related to the different $\mathrm{P}$ (mass) loading rates.

Both Ca-bound $\mathrm{P}$ and exchangeable $\mathrm{Ca}$ decrease with depth. For Rubicon, the concentration of Ca-bound $\mathrm{P}$ increases from $275 \mathrm{mg} / \mathrm{kg}$ at the depth of $0-15 \mathrm{~cm}$ to 284 $\mathrm{mg} / \mathrm{kg}$ at the depth of $15-30 \mathrm{~cm}$, but the concentration of the exchangeable Ca decreases sharply from 1205 to $631 \mathrm{mg} /$ $\mathrm{kg}$ in the corresponding depth (Figure la). For Roscommon, the Ca-bound P concentration does not change much after the $30-\mathrm{cm}$ depth, but the corresponding Ca concentration reduces from 170 to $50 \mathrm{mg} / \mathrm{kg}$. Therefore, the trend of the Ca-bound $P$ profiles does not match that of the exchangeable Ca profiles very well, indicating that $\mathrm{P}$ might not have saturated the Ca adsorbed in the Muskegon soils.

The 1-day $P_{\max }$ of the topsoils has increased by $\sim 3$ times since 1973 (Table 4). While the 1-day $P_{\max }$ decreases along the depth (Figure 1), a larger 1-day $P_{\max }$ corresponds to a higher concentration of exchangeable $\mathrm{Ca}$ (Figures 1 and 2); the 1-day $P_{\max }$ could be significantly influenced by the quantity of exchangeable Ca adsorbed in the soil (Figure 2). 


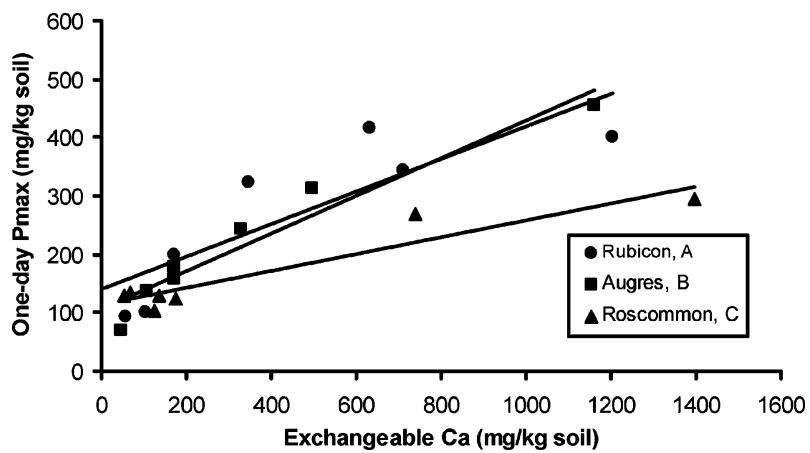

FIGURE 2. Relationship between exchangeable Ca and maximum $P$ sorption capacity of Muskegon soils (data from profiles in Figure 1). The straight lines can be represented by $Y=a X+b$, where $Y$ $=$ 1-d $P_{\max }, X=$ exchangeable $\mathrm{Ca}, a=$ the slope, and $b=$ the interception. For Rubicon, $a=0.2811, b=140.39, R^{2}=0.71, t$ value $=3.1932$ at $p<0.025$; for AuGres, $a=0.3282, b=108.03, R^{2}=0.93$, $t$ value $=35.3891$ at $p<0.005$; for Roscommon, $a=0.1463, b=113.6$, $R^{2}=0.88, t$ value $=6.3327$ at $p<0.005$.

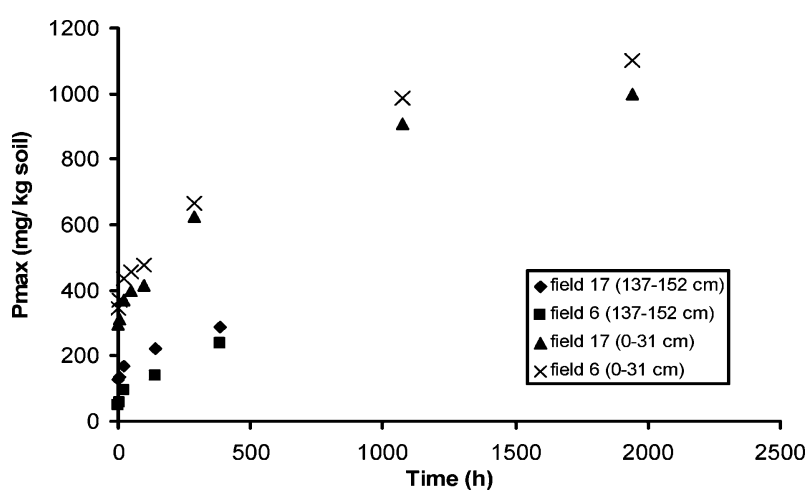

FIGURE 3. Time-dependent $\boldsymbol{P}_{\max }$ data from $\mathbf{P}$ sorption isotherms batch tests. Soils at the depth of $0-30 \mathrm{~cm}(0-12$ in.) contained 917 and $830 \mathrm{mg} / \mathrm{kg}$ exchangeable $\mathrm{Ca}$ and at $137-152 \mathrm{~cm}(54-60 \mathrm{in}$.) contained 102 and $106 \mathrm{mg} / \mathrm{kg}$ exchangeable Ca for Rubicon and AuGres, respectively.

The exchangeable Ca may be a useful parameter for predicting the 1-day $P_{\max }$ of the soils.

Although we evaluated the 1-day $P_{\max }$ of the soils, still we know neither the exact $P_{\max }$ of the soils at the Muskegon site nor how and why the Ca ions adsorbed in the soils affect the 1-day $P_{\max }$. It has been reported that the real $\mathrm{P}$ adsorption capacity in the field is about 3-5 times higher than that of the estimated 1-day $P_{\max }(1,33)$. Results of our long-term $\mathrm{P}$ adsorption tests show that the $P_{\max }$ increases with adsorption time during the batch tests (Figure 3 ). The $P_{\max }$ did not approach its maximum value even after 390- and 2000-h adsorption for the soils at two different depths. It should be noted, however, that these $P_{\max }$ tests appear to be a highly artificial measurement, as high $\mathrm{P}$ and Ca doses are added; in the real situation with lower concentrations this $P_{\max }$ may never be reached anyway. Nevertheless, the results of the $P_{\max }$ tests indicate that it is possible for the soil to continuously adsorb $\mathrm{P}$, and it is difficult to obtain an absolute $P_{\max }$ with isotherm tests within a reasonably short period.

Implications. For the Muskegon County wastewater land treatment system, changes in soil $\mathrm{pH}$ and the amount of $\mathrm{Ca}$ adsorbed by the soil are significant and have not been reported in the past. As a result of these changes, the major inorganic $\mathrm{P}$ form in the soil is Ca-bound P. Results indicate that the amount of $\mathrm{Ca}$ adsorbed in the soil also affects the $\mathrm{P}$ adsorption capability of the soil. Our results are strongly related to evaluation of (1) P accumulation and (2) P leaching potential in a land wastewater treatment system, as elaborated below.
(1) Currently, the exact mechanisms of P adsorption onto the soil with a large amount of Ca are not known. While most of the applied P has been accumulated in the topsoil at the Muskegon site, we did identify different forms of $\mathrm{P}$ in deeper soils. Considering the higher P loading rate of Rubicon $(0.12$ $\mathrm{kg} / \mathrm{m}^{2}$ ) and the $1-\mathrm{d} P_{\max }$ of Rubicon being much less than its saturation value (Figure 3) at the topsoil $(0-15 \mathrm{~cm})$, it is possible that some of the $\mathrm{P}$ in wastewater is not adsorbed or precipitated quickly enough in the topsoil and thereby, moves down with the wastewater. This inference seems to be supported by the two-stage theory for the reaction of $\mathrm{P}$ with Ca (34). The initial adsorption (as the first stage) is thought to occur at certain sites where lateral interaction between phosphate ions produces surface clusters that then act as nuclei for subsequent crystal growth (the second stage). The second stage is much slower than the first stage (34). On the basis of this two-stage theory, it can be deduced that $\mathrm{P}$ buildup is from the topsoil and moves down deeper and deeper, and any P moving downward through the soil should eventually react with Ca ions. Therefore, the Ca sorption capacity of the soil becomes an important parameter for predicting the $\mathrm{P}$ leaching potential and, furthermore, the life expectancy of a land treatment system.

(2) Labile P distribution is not correlated with that of total $\mathrm{P}$, nor Fe-bound $\mathrm{P}$, nor $\mathrm{Ca} / \mathrm{Mg}$-bound $\mathrm{P}$ and, thus, may not be a good indicator for predicating $P$ leaching in a wastewater land treatment system. On the basis of the 10-year soil test data (data not shown) of the Muskegon soils, the Bray-1 P (35) is not suitable for the predicting purpose, because the Bray-P fluctuated in these years, instead of increasing with the accumulation of the total P. Recent studies suggest using the DPS (degree of phosphorus saturation) to evaluate the soil $\mathrm{P}$ release potential. Our results indicate that the exchangeable Ca has a good relationship with the 1-day $\mathrm{P}$ maximum adsorption capacity of the soil. In addition, we found that the major forms of $\mathrm{P}$ in the Muskegon soils are $\mathrm{Ca}$ - and Fe-bound $\mathrm{P}$. Therefore, it may be possible to develop an index that is similar to the DPS and accounts for the effects of $\mathrm{Ca}$ adsorption and $\mathrm{Ca}$-bound $\mathrm{P}$ on $\mathrm{P}$ leaching potential in soils of a land treatment system.

Results of this study challenge the current knowledge on $\mathrm{P}$ fate and transport in soils of land treatment systems. Currently, we do not have the answers for several important questions, such as, how will the wastewater properties affect the adsorption of $\mathrm{Ca}$ and, thereby, $\mathrm{P}$ in the soil? How are the wastewater application rate and the soil adsorption capacity for $\mathrm{Ca}$ and $\mathrm{P}$ linked with $\mathrm{P}$ leaching from the land treatment system and, thus, the life expectancy of the system? An extended question would be whether the phenomenon of the $\mathrm{Ca}$ and $\mathrm{P}$ accumulation capacity increasing with longterm wastewater application also occurs in other wastewater land treatment systems. Further studies are needed to answer these questions.

\section{Acknowledgments}

The authors wish to thank Mr. Dave Kendrick, the manager of the Muskegon wastewater treatment plant, for providing the site information, some soil samples collected in 1973, and convenience during the soil sampling and field studies. This research was supported by the U.S. Environmental Protection Agency (EPA) Region 7 (Project\#: 3K-3176-NAEX) with the matching fund provided by the College of Engineering at UNL.

\section{Literature Cited}

(1) U.S. EPA Process Design Manual-Land Treatment of Municipal Wastewater. EPA 625/1-81-013 (COE EM 1110-1-501). Center for Environmental Research Information, U. S. EPA, Cincinnati, OH, 1981. 
(2) Harter, R. D.; Foster, B. B. Computer simulation of phosphorus movement through soils. Soil Sci. Soc. Am. J. 1976, 40, 239-242.

(3) Overman, A. R.; Scholtz, R. V. Langmuir-Hinshelwood model of soil phosphorus kinetics. Communications Soil Science and Plant Analysis 1999, 30 (1\&2), 109-119.

(4) Enfield, C. G.; Leach, L E. Phosphorus model of Muskegon wastewater system. J. Environ. Eng. 1975, 101, 911-916.

(5) Gaynor J. D.; Findlay, W. I. Soil and phosphorus loss from conservation and conventional tillage in corn production. $J$. Environ. Qual. 1995, 24, 734-741.

(6) Sharpley, A.; Foy, B.; Withers, P. Practical and innovative measures for the control of agricultural phosphorus losses to water: An overview. J. Environ. Qual. 2000, 29, 1-9.

(7) Hesketh, N.; Brookes, P. C. Development of an indicator for risk of phosphorus leaching. J. Environ. Qual. 2000, 29, 105-110.

(8) Schoumans, O. F.; Groenendijk, P. Modeling soil phosphorus levels and phosphorus leaching from agricultural land in The Netherlands. J. Environ. Qual. 2000, 29, 111-116.

(9) Sinaj, S.; Stamm, C.; Toor, G. S.; Condron, L. M.; Hendry, T.; Di, H. J.; Cameron, K. C.; Frossard, E. Phosphorus exchangeability and leaching losses from two grassland soils. J. Environ. Qual. 2002, 31, 319-330.

(10) McDowell, R.; Sharpley, A.; Withers, P. Indicator to predict the movement of phosphorus from soil to subsurface flow. Environ. Sci. Technol. 2002, 36, 1505-1509.

(11) Sims, J. T.; Simard, R. R.; Joern, B. C. Phosphorus loss in agriculture drainage: Historical perspective and current research. J. Environ. Qual. 1998, 27, 277-293.

(12) USDA Soil Surveys: Muskegon County Michigan. Michigan State Conservationist: East Lansing, MI, October 1968

(13) Ellis, B. G.; Erickson, A. E.; Wolcott, A. R.; Knezak, B. D.; Tiedje, T. M.; Butcher, J. Applicability of Land Treatment of Wastewater in The Great Lakes Area Basin: Effectiveness of Sandy Soils at Muskegon County, Michigan, for Renovating Wastewater. U.S. EPA report. 905/9-79-006-B. U.S. Government Printing Office: Washington, DC, 1979.

(14) Biegel, C. M.; Lee, L. S.; Graveel., J. G.; Vorst, J. J. Muskegon County wastewater management: an effluent application decision case study. J. Nat. Resour. Life Sci. Educ. 1998, 27, 137144.

(15) Pierzynski, G. M. (ed.); Methods of phosphorus analysis for soils, sediments, residuals, and waters. Southern Cooperative Series Bulletin No. \#396. URL, North Carolina State University, <http://www.soil.ncsu.edu/sera17/publications/sera17-2/ pm_cover.htm>, 2000.

(16) Pettersson, K.; Istvanovics, V. Sediment phosphorus in Lake Balaton-forms and mobility. Ergeb. Limnol. 1988, 30, 25-41.

(17) Nair, V. D.; Graetz, D. A.; Portier, K. M. Forms of phosphorus in soil profiles from dairies of south Florida. Soil Sci. Soc. Am. J. 1995, 59, 1244-1249.

(18) Murphy, J.; Riley, J. P. A modified single solution method for the determination of phosphate in natural waters. Anal. Chim. Acta. 1962, 27, 31-36.
(19) Olsen, S. R.; Sommers, L. E. Phosphorus. In Methods of Soil Analysis. Part 2. Agronomy No. 9, 2nd ed.; Page, A. L., Miller, R. H., Keeney, D. R., Eds.; American Society of Agronomy: Madison, WI, 1982; pp 403-430.

(20) Schofield, R. K.; Taylor, A. W. The measurement of soil pH. Soil Sci. Soc. Am. Proc. 1955, 19, 164-167.

(21) McKeague, J. A.; Day, J. H. Dithionate and oxalate-extractable $\mathrm{Fe}$ and $\mathrm{Al}$ as aids in differentiating various classes of soils. Can. J. Soil Sci. 1966, 46, 13-22.

(22) McLean, E. O. Aluminum. In Methods of Soil Analysis, Part 2. Agronomy 9; Black, C. A., Ed.; American Society of Agronomy: Madison, WI, 1965; pp 978-998.

(23) Schollenberger, C. J.; Simon, R. H. Determination of exchange capacity and exchangeable bases in soil-ammonium acetate method. Soil Sci. 1945, 59, 13-24.

(24) Davies, B. E. Loss-on-ignition as an estimate of soil organic matter. Soil Sci. Soc. Am. Proc. 1974, 38, 150-151.

(25) McKeague, J. A.; Sheldrick, B. H. A comparison of some methods for determining carbonates in soils. Can. J. Soil Sci. 1976, 56, $125-127$.

(26) Lindsay, W. L. Chemical Equilibria in Soil; John Wiley \& Sons: New York, 1979.

(27) Isensee, A. R.; Walsh, L. M. Influence of banded fertilizer on the chemical environment surrounding the band. II. effect on soilsolution cation, cation-anion balance and solution phosphorus. J. Sci. Food Agric. 1972, 23, 509-516.

(28) Cho, C. M. Phosphate transport in calcium-saturated systems: I. Theory. Soil Sci. Soc. Am. J. 1991, 55, 1275-1281.

(29) Bunzl, K.; Schmidt, W.; Sansoni, B. Kinetics of ion exchange in soil organic matter: IV. Adsorption and desorption of $\mathrm{Pb}^{2+}$ $\mathrm{Cu}^{2+}, \mathrm{Zn}^{2+}$ and $\mathrm{Ca}^{2+}$ by peat. J. Soil Sci. 1976, 27, 32-41.

(30) Ryan, J.; Curtin, D.; Cheema, M. A. Significance of iron oxides and calcium carbonate particle size in phosphate sorption by calcareous soils. Soil Sci. Soc. Am. J. 1984, 48, 74-76.

(31) Soils, P.; Torrent, J. Phosphate sorption by calcareous vertisols and inceptisols of Spain soils. Soil Sci. Soc. Am. J. 1989, 54, 456-459.

(32) Van Dijk, H. Cation binding of humic acids. Geoderma 1971, $5,53-67$.

(33) Van der Zee, S. E. A. T. M.; Fokkink, L. G. J.; Van Riemsdijk, W. H. A new technique for assessment of reversibly adsorbed phosphate. Soil Sci. Soc. Am. J. 1987, 51, 599-604.

(34) Freeman, J. S.; Rowell, D. L. The adsorption and precipitation of phosphate onto calcite. J. Soil Sci. 1981, 32, 75-84.

(35) Bray, R. H.; Kurtz, L. T. Determination of total organic and available forms of phosphorus in soils. Soil Sci. 1945, 59, 3945.

Received for review March 17, 2005. Revised manuscript received July 18, 2005. Accepted July 19, 2005.

ES050526P 